\title{
KAJIAN PENGGUNAAN WETFIX BE PADA BETON ASPAL CAMPURAN PANAS BERGRADASI SUPERPAVE
}

\author{
Rikki Sofyan Rizal ${ }^{1}$, Anni Susilowati ${ }^{2}$, Heri Susanto ${ }^{3}$ \\ Jurusan Teknik Sipil ${ }^{1,2}$, PT Jasa Marga (Persero) Tbk $^{3}$ \\ Politeknik Negeri Jakarta ${ }^{1,2}$ \\ Kampus UI Depok ${ }^{1,2}$, \\ rikkisofyan@gmail.com ${ }^{1}$, annisusilowati@yahoo.com ${ }^{2}$, herisusanto383@gmail.com $^{3}$
}

\begin{abstract}
Abstrak
Penelitian ini bertujuan untuk mengevaluasi penggunaan Wetfix BE pada beton aspal campuran panas bergradasi superpave untuk lapis aus perkerasan lentur, dilihat dari aspek mutu, yaitu karakteristik Marshall, deformasi dan kekesatan permukaan, serta biaya. Pada penelitian ini variasi penggunaan Wetfix BE yang di gunakan adalah $0.0 \%$, $0.2 \%, 0.3 \%$, dan $0.4 \%$ dari KAO 6\%. Dari hasil penelitian yang didapat penggunaan Wetfix $B E$ dalam campuran aspal tidak sepenuhnya meningkatkan nilai karakteristik Marshall karena ada beberapa sifat Marhall seperti pelelehan dan Marshall Quotient yang tidak memenuhi spesifikasi. Nilai Mu-Meter untuk campuran tanpa dan dengan menggunakan Wetfix $B E$ memenuhi persyaratan, yaitu lebih dari $0.33 \mathrm{Mu}-$ Meter, dengan demikian maka permukaan jalan memiliki tahanan gesek antara ban dan permukaan jalan yang cukup baik. Dari hasil pengujian alur roda pada suhu $60^{\circ} \mathrm{C}$ beton aspal yang lebih tahan terhadap deformasi yaitu pada kadar Wetfix BE $0.0 \%$. Untuk biaya, beton aspal normal lebih murah Rp 14,813 per ton dari aspal dengan bahan tambah Wetfix BE $0.3 \%$. Perbedaan biaya yang terjadi tidak terlalu berarti karena beton aspal dengan bahan tambah Wetfix $B E$ $0.3 \%$ hanya mengalami kenaikan harga $1.43 \%$ dari beton aspal normal.
\end{abstract}

Kata kunci :

Laston, Superpave, Wetfix BE, Marshall, Mu-Meter, Deformasi, Biaya

\section{Abstract}

This research aims to evaluate the uses of Wetfix $B E$ in graded superpave asphalt concrete hot mix for wearing course layers of flexible pavement, from the aspect of quality, which is characteristic of Marshall, deformation, surface roughness, and costs. In this research the use of Wetfix BE variations were $0.0 \%$, $0.2 \%, 0.3 \%$, and $0.4 \%$ of the KAO 6\%. From the research, the use of Wetfix $B E$ in the asphalt mixture didn't fully enhance the value of Marshall characteristics because there were some properties Marshall such as flow and Marshall Quotiet which were meet the specifications. Mu-Meter values for mixture using Wetfix $B E$ and without using Wetfix $B E$ met the requirements of more than $0.33 \mathrm{Mu}$-Meter, the surface of the road would have a good frictional resistance between the tires and the road surface. From the results of wheel tracking test at $60^{\circ} \mathrm{C}$, asphalt concrete without using Wetfix BE was more resistant to deformation. From the aspect of cost, asphalt concrete without Wetfix BE was $R p 14.813$ per ton cheaper than the asphalt whit Wetfix $B E$ $0.3 \%$.

Keywords :

Laston, Superpave, Wetfix BE, Marshall, Mu-Meter, Deformation, Cost

\section{Pendahuluan}

Lapis ulang pada umumnya menggunakan Laston (lapis aspal beton). Laston memiliki tingkat fleksibilitas yang tinggi, juga rentan terhadap kerusakan yang diakibatkan oleh repetisi beban tinggi kendaraan sehingga mengakibatkan deformasi atau yang permanen. Berdasarkan permasalahan tersebut maka diperlukan suatu modifikasi campuran aspal dan agregat. Salah satunya adalah dengan metode memodifikasi campuran tersebut dengan menggunakan gradasi Superpave (Superior 
Performance Asphalt Pavement). Metode ini diperkenalkan oleh Federal Highway Administration (FHWA) di Amerika Serikat pada tahun 1987 hingga 1993. Meskipun campuran ini tahan terhadap rutting, akan tetapi hasil yang sudah ada di Illinois, Amerika Serikat, beton campuran beraspal panas yang menggunakan metode ini lebih rendah ketahannnya terhadap air. Dengan demikian sebagai upaya menutupi kekurangan gradasi superpave, maka diperlukan bahan tambah, salah satunya yaitu wetfix $B E$. Wetfix $B E$ yang merupakan bahan kimia anti stripping dan berguna untuk meningkatkan ikatan dan menstabilkan campuran antara agregat dan aspal terutama pada musim hujan.

\section{KAJIAN LITERATUR}

\section{II.1 Beton Aspal Campuran Panas}

Beton aspal adalah jenis perkerasan jalan yang terdiri dari campuran agregat dan aspal, dengan atau tanpa bahan tambahan (Sukirman, 2003). Berdasarkan fungsinya aspal beton campuran panas dapat diklasifikasikan sebagai berikut:

a. Sebagai lapis permukaan yang tahan terhadap cuaca, gaya geser dan tekanan roda serta memberikan lapis kedap air yang dapat melindungi lapis di bawahnya dari rembesan air.

b. Sebagai lapis pondasi atas.

c. Sebagai lapis pembentuk pondasi, jika dipergunakan pada pekerjaan peningkatan atau pemeliharaan jalan.

Sesuai dengan fungsinya maka lapis aspal beton mempunyai kandungan agregat dan aspal yang berbeda. Sebagai lapis aus, maka kadar aspal yang dikandungnya haruslah cukup sehingga dapat memberikan lapis yang kedap air dan mempunyai daya lekat yang cukup tinggi. Campuran aspal beton mempunyai 3 macam campuran yaitu:

a. AC-WC (Asphalt Concrete Wearing Course), sebagai lapisan yang kedap terhadap air dan cuaca serta lapisan aus yang langsung berhubungan dengan ban kendaraan. Diameter butir maksimal 19,0 mm dan bertekstur halus.

b. AC-BC (Asphalt Concrete Binder Course), sebagai lapisan yang terletak di bawah lapisan aus dan bisa terletak di antara lapisan $A C$ - WC dan AC-Base. Diameter butir maksimal 25,4 $\mathrm{mm}$ dan bertekstur sedang.

c. AC-Base (Asphalt Concrete Base), laston sebagai lapis pondasi. Diameter butir maksimal $37,5 \mathrm{~mm}$ dan bertekstur kasar.

\section{II.2 Gradasi Superpave}

Tipikal gradasi menerus Superpave didefinisikan sebagai jenis agregat campuran untuk perkerasan yang mempunyai kemampuan pelayanan lalu lintas paling baik (Super Performance Pavement).

Superpave menetapkan gradasi dengan 2 (dua) spesifikasi khusus yaitu target gradasi berada dalam batas titik-titik control (control point) dan menghindari daerah penolakan (restricted zone). Titik-titik control berfungsi sebagai batas rentang dimana suatu target gradasi harus lewat. Titik-titik tersebut diletakkan di ukuran maksimum nominal dan di pertengahan saringan $(2.36 \mathrm{~mm})$ dan ukuran saringan terkecil $(0.075 \mathrm{~mm})$.

Daerah penolakan terletak diantara pertengahan saringan dan saringan $0.3 \mathrm{~mm}$. Gradasi yang melewati daerah penolakan tersebut disebut "humped gradation" karena bentuk hump (punggung bukit) di daerah ini. Di dalam campuran, daerah penolakan ini menunjukkan terlalu banyak pasir halus dari seluruh total pasir, sehingga mengalami kesulitan dalam pemadatan dan mengurangi ketahanan terhadap deformasi semala umur rencana. Gradasi yang mengikuti garis kepadatan (density) maksimum seringkali memberikan VMA (void in mineral aggregate) yang tidak mencukupi untuk memberikan kadar aspal yang sesuai dalam menghasilkan keawetan campuran agregat aspal.

Agregat bergradasi superpave yang digunakan pada campuran agregat aspal bertujuan untuk meningkatkan kinerja campuran tersebut dengan mengontrol deformasi permanen, retak pada temperatur, dan keretakan akibat kelelehan.

\section{II.3 Wetfix BE}

Wetfix $B E$ adalah bahan kimia anti striping yang disarankan dosis pemakaiannya yaitu $0,3 \%$ terhadap kadar aspal, berguna untuk meningkatkan ikatan dan menstabilkan campuran antara agregat dan aspal terutama pada musim hujan. 
Wetfix $B E$ tahan dalam suhu $170{ }^{\circ} \mathrm{C}$ secara terus menerus selama dalam jangka waktu 5 hari, tetapi apabila lewat 5 hari akan terjadi penurunan efektifitasnya. Dibandingkan dengan zat aditif lainnya, penggunaan wetfix $B E$ dinilai sangat efisien dan ekonomis karena penggunannya hanya sedikit terhadap kadar aspal dan bisa menghasilkan struktur perkerasan yang maksimal. Keuntungan lain menggunakan zat aditif wetfix $B E$ pada perkerasan jalan yaitu:

a. Sebagai modifier aspal untuk meningkatkan ikatan agregat dan aspal.

b. Dapat digunakan untuk berbagai macam jenis agregat.

c. Pemeliharaan rutin menjadi berkurang.

d. Dapat memperpanjang umur jalan 3-4 tahun.

e. Jalan selalu baik terpelihara dan nyaman.

\section{Metodologi Penelitian}

Untuk mencapai tujuan dan menjawab permasalahan penelitian diperlukan pengambilan data di laboratorium. Penelitian ini dilakukan di laboratorium bahan PNJ (Politeknik Negeri Jakarta) dan di Balai Bahan dan Perkerasan Jalan Pusat Penelitian Jalan dan Jembatan, Departemen Pekerjaan Umum Bandung. Sedangkan standar-standar pengujian yang digunakan menggunakan standar RSNI XXXX-2014, SNI, ASTM.

Dalam penelitian ini pengujian dilakukan secara bertahap, yang terdiri dari pengujian agregat (agregat kasar, agregat halus, dan filler), aspal, dan pengujian terhadap campuran yang terdiri dari Uji Marshall, Kepadatan Membal (Refusal Density), Stabilitas Sisa, Wheel Tracking dan kekesatan permukaan.

Untuk pengujian agregat terdiri dari pengujian berat jenis, pengujian berat isi, analisa ayak, pengujian kadar air, dan pengujian kadar lumpur. Sedangkan Pengujian aspal terdiri dari pengujian berat jenis, pengujian penetrasi, pengujian daktilitas, pengujian titik nyala, pengujian titik lembek. Metode yang digunakan untuk pengujian campuran adalah metode Marshall, dimana dari pengujian Marshall tersebut didapatkan hasil yang berupa komponenkomponen Marshall, yaitu stabilitas, flow, void in total mix (VITM), void filled with asphalt, dan kemudian didapatkan nilai Marshall Quotient (MQ).
Pengujian di lanjutkan dengan uji alur roda untuk mengetahui kinerja campuran tersebut.

Untuk pembuatan benda uji disajikan pada Tabel 3.1. sampai dengan Tabel 3.3.

Tabel 3.1. Kebutuhan Benda Uji Pengujian Marshall Tahap Pertama

\begin{tabular}{|c|c|c|c|}
\hline No & Pengujian & Kadar Aspal & Jumlah \\
\hline \multirow{5}{*}{1} & \multirow{5}{*}{ Marshall } & $-1.0(5.0 \%)$ & 3 \\
\hline & & $-0.5(5.5 \%)$ & 3 \\
\hline & & $\mathrm{Pb} \quad(6.0 \%)$ & 3 \\
\hline & & $+0.5(6.5 \%)$ & 3 \\
\hline & & $+1.0(7.0 \%)$ & 3 \\
\hline \multirow{3}{*}{2} & \multirow{3}{*}{$\begin{array}{c}\text { Kepadatan } \\
\text { Membal }\end{array}$} & $5.5 \%$ & 2 \\
\hline & & $6.0 \%$ & 2 \\
\hline & & $6.5 \%$ & 2 \\
\hline 3 & $\begin{array}{l}\text { Stabilitas } \\
\text { Sisa }\end{array}$ & $\begin{array}{cc}\text { KAO (6\%) } & \text { Waktu } \\
& \begin{array}{c}\text { Perendaman } \\
24 \text { jam }\end{array} \\
\end{array}$ & 3 \\
\hline
\end{tabular}

Tabel 3.2. Kebutuhan Benda Uji Pengujian Marshall Tahap Kedua

\begin{tabular}{|c|c|c|c|c|c|c|c|}
\hline \multirow[t]{2}{*}{ No } & \multirow[t]{2}{*}{ Pengujian } & \multirow{2}{*}{\multicolumn{2}{|c|}{ Kadar Aspal }} & \multicolumn{3}{|c|}{$\begin{array}{l}\text { Benda Uji dengan } \\
\text { Kadar Wetfix } B E\end{array}$} & \multirow[t]{2}{*}{ Jumlah } \\
\hline & & & & $0.2 \%$ & $0.3 \%$ & $0.4 \%$ & \\
\hline 1 & Marshall & & $\mathrm{AO}(6 \%)$ & 3 & 3 & 3 & 9 \\
\hline \multirow{2}{*}{2} & \multirow{2}{*}{$\begin{array}{l}\text { Stabilitas } \\
\text { Sisa }\end{array}$} & \multirow{2}{*}{$\begin{array}{l}\mathrm{KAO} \\
(6 \%)\end{array}$} & $\begin{array}{c}\text { Waktu } \\
\text { Perendaman } \\
30 \text { Menit }\end{array}$ & 3 & 3 & 3 & 9 \\
\hline & & & $\begin{array}{c}\text { Waktu } \\
\text { Perendaman } \\
24 \text { Jam }\end{array}$ & 3 & 3 & 3 & 9 \\
\hline
\end{tabular}

Tabel 3.2. Kebutuhan Benda Uji Alur Roda (Wheel Tracking) dan Kekesatan

\begin{tabular}{|c|c|c|c|c|c|c|c|}
\hline \multirow[t]{2}{*}{ No } & \multirow[t]{2}{*}{ Pengujian } & \multirow{2}{*}{$\begin{array}{c}\text { Kadar } \\
\text { Aspal }\end{array}$} & \multicolumn{4}{|c|}{$\begin{array}{c}\text { Benda Uji dengan Kadar Wetfix } \\
\qquad E\end{array}$} & \multirow[t]{2}{*}{ Jumlah } \\
\hline & & & $0.0 \%$ & $0.2 \%$ & $0.3 \%$ & $0.4 \%$ & \\
\hline 1 & $\begin{array}{l}\text { Uji Alur } \\
\text { Roda } \\
\text { (Wheel } \\
\text { Tracking } \\
\text { Machine) }\end{array}$ & $\begin{array}{l}\mathrm{KAO} \\
(6 \%)\end{array}$ & 2 & 2 & 2 & 2 & 8 \\
\hline 2 & $\begin{array}{c}\text { Uji } \\
\text { Kekesatan }\end{array}$ & $\begin{array}{r}\mathrm{KAO} \\
(6 \%)\end{array}$ & 2 & 2 & 2 & 2 & 8 \\
\hline
\end{tabular}

\section{Analisis dan Perancangan}

\section{IV.1 Hasil Pengujian Sifat Fisik Agregat}

Berikut hasil yang didapatkan dari pengujian sifat fisik agregat yang telah di lakukan di laboratorium. 
Tabel 4.1. Hasil Pengujian Sifat Fisik Agregat Halus

\begin{tabular}{lcccc}
\hline \multirow{2}{*}{ Pengujian } & \multicolumn{2}{c}{ Persyaratan } & \multirow{2}{*}{ Hasil } & \multirow{2}{*}{ Keterangan } \\
\cline { 2 - 3 } & Minimal & Maksimal & & \\
\hline Berat Jenis & & & & \\
- Bulk & 2.5 & - & 2.59 & Memenuhi \\
- SSD & 2.5 & - & 2.64 & Memenuhi \\
- Semu & 2.5 & - & 2.74 & Memenuhi \\
Penyerapan Air (\%) & - & 3 & 2.15 & Memenuhi \\
Kadar Lumpur (\%) & - & 1 & 0.84 & Memenuhi \\
\hline
\end{tabular}

Tabel 4.2. Hasil Pengujian Sifat Fisik Agregat Kasar

\begin{tabular}{lcccc}
\hline \multirow{2}{*}{ Pengujian } & \multicolumn{2}{c}{ Persyaratan } & \multirow{2}{*}{ Hasil } & \multirow{2}{*}{ Keterangan } \\
\cline { 2 - 3 } & Minimal & Maksimal & & \\
\hline Berat Jenis & & & & \\
- Bulk & 2.5 & - & 2.59 & Memenuhi \\
- SSD & 2.5 & - & 2.64 & Memenuhi \\
- Semu & 2.5 & - & 2.74 & Memenuhi \\
Penyerapan Air (\%) & - & 3 & 2.15 & Memenuhi \\
Kadar Lumpur (\%) & - & 1 & 0.84 & Memenuhi \\
\hline
\end{tabular}

Dari hasil pengujian sifat fisik agregat, baik untuk agregat halus maupun agregat kasar semuanya memenuhi Spesifikasi Umum Bidang Jalan dan Jembatan Pusat Litbang Pd-T-04-2005B.

\section{IV.2 Hasil Pengujian Aspal}

Dalam penelitian ini digunakan aspal dengan penetrasi 60/70. Adapun untuk spesifikasi yang digunakan berdasarkan RSNI XXXX-2014. Berikut hasil pengujian aspal yang sudah ditabelkan.

Tabel 4.3. Hasil Pengujian Aspal

\begin{tabular}{lccccccc}
\hline \multirow{2}{*}{ Pengujian } & Satuan & \multicolumn{3}{c}{ Kadar Wetfix BE } & \multicolumn{3}{c}{$\begin{array}{c}\text { Spesifikasi RSNI3 } \\
\text { XXXX-2014 }\end{array}$} \\
\cline { 2 - 8 } & & $\mathbf{0 . 0 0 \%}$ & $\mathbf{0 . 2 0 \%}$ & $\mathbf{0 . 3 0 \%}$ & $\mathbf{0 . 4 0 \%}$ & Min & Mak \\
\hline Berat Jenis & - & 1.02 & 1.02 & 1.02 & 1.03 & 0.92 & 1.06 \\
Penetrasi & $\mathrm{mm}$ & 68 & 64 & 65 & 67 & 60 & 70 \\
Titik Lembek & ${ }^{\circ} \mathrm{C}$ & 48.00 & 48.50 & 48.50 & 46.00 & 48 & - \\
Daktilitas & $\mathrm{cm}$ & 103.50 & 71.00 & 101.00 & 77.00 & 100 & - \\
\hline
\end{tabular}

Dari pengujian aspal yang telah di lakukan, untuk titik lembek dengan kadar Wetfix BE $0.4 \%$ serta daktilitas dengan kadar Wetfix BE $0.2 \%$ dan $0.4 \%$ nilainya tidak memenuhi spesifikasi RSNI3 XXXX2014.

\section{IV.3 Hasil Pengujian Marshall Tahap Pertama}

Pengujian Marshall tahap pertama ini bertujuan untuk mendapatkan Kadar Aspal Optimum (KAO), yang akan di gunakan untuk pengujian Marshall tahap kedua. Berikut hasil pengujian marshall tahap pertama.

Tabel 4.4. Hasil Pengujian Marshall Tahap Pertama

\begin{tabular}{lcccccc}
\hline \multirow{2}{*}{\multicolumn{1}{c}{ Sifat Campuran }} & \multicolumn{6}{c}{ Persentase Aspal (\%) } \\
\cline { 2 - 6 } & $\mathbf{5}$ & $\mathbf{5 . 5}$ & $\mathbf{6}$ & $\mathbf{6 . 5}$ & $\mathbf{7}$ & \\
\hline \%Rongga Thd Agregat (VMA) & 17.03 & 17.09 & 17.85 & 18.69 & 19.62 & $\min 15$ \\
\%Rongga Terisi Aspal (VFB) & 64.25 & 70.75 & 73.02 & 76.31 & 78.65 & $\min 65$ \\
\%Rongga Thd Campuran (VIM) & 6.09 & 5.00 & 4.85 & 4.42 & 4.14 & $3.0-5.0$ \\
Stabilitas & 1777.08 & 1528.36 & 1700.91 & 1798.74 & 1042.57 & $\min 800$ \\
Kelelehan & 3.24 & 3.81 & 3.46 & 3.02 & 4.15 & 2.4 \\
Marshall Quotient & 560.92 & 473.63 & 523.09 & 648.13 & 249.52 & $\min 250$ \\
\hline
\end{tabular}

Setelah seluruh properties aspal telah diketahui, maka dapat ditentukan kadar aspal optimum dari pengujian Marshall ini. Untuk mendapatkan kadar aspal optimum dibuatlah suatu grafik marshall pada Gambar 4.1. berikut.

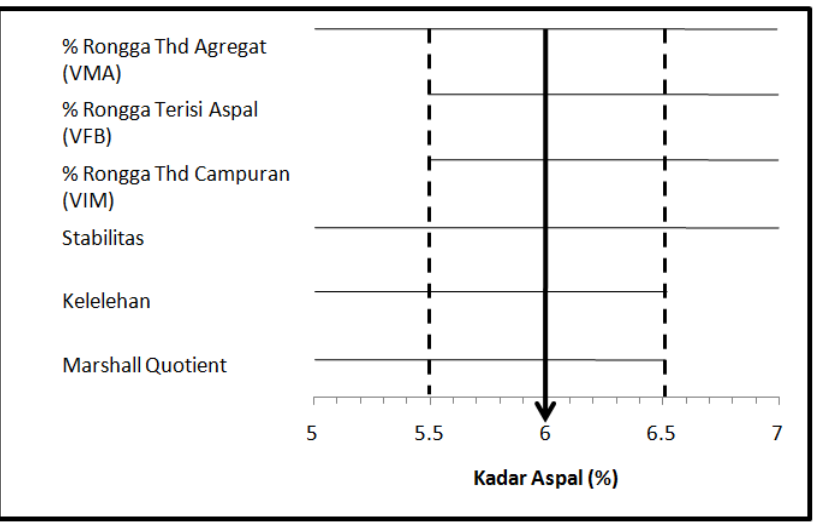

\section{Gambar 4.1. Grafik Hasil Marshall}

Dari hasil nilai karakteristik campuran yang dihasilkan pada pengujian Marshall pada Gambar 5.12., berdasarkan spesifikasi serta hasil analisis, diketahui seluruh parameter Marshall yang memenuhi persyaratan terletak pada rentang kadar aspal 5,5\% $6.5 \%$. Dari hasil tersebut dapat disimpulkan bahwa:

Kadar Aspal Optimum $=\{(5,0 \%+6.5 \%): 2\}=6.0 \%$ 
Karena nilai kadar aspal optimum yang di dapat sama dengan perkiraan kadar aspal, maka untuk nilai propersties Marshall untuk kadar aspal optimum ini di ambil berdasarkan perkiraan kadar aspal $6.0 \%$ yang telah di lakukan.

\section{IV.4 Hasil Pengujian Marshall Tahap Kedua}

Setelah di dapat kan KAO 6\%, maka dilakukan pengujian Marshall tahap kedua dengan penambahahan Wetfix BE $0.0 \%, 0.2 \%, 03 \%$, dan $0.4 \%$ dari KAO. Berikut hasil pengujian Marsahall tahap kedua.

Tabel 4.4. Hasil Pengujian Marshall Tahap Kedua

\begin{tabular}{|c|c|c|c|c|c|}
\hline \multirow{2}{*}{ Sifat Campuran } & \multicolumn{4}{|c|}{ Persentase Wetfix BE } & \multirow{2}{*}{ Spesifikasi } \\
\hline & $0.00 \%$ & $0.20 \%$ & $0.30 \%$ & $0.40 \%$ & \\
\hline$\%$ Rongga Thd Agregat(VMA) & 17.85 & 18.28 & 18.09 & 18.08 & $\min 15$ \\
\hline \% Rongga Terisi Aspal(VFB) & 73.02 & 71.54 & 72.42 & 72.48 & $\min 65$ \\
\hline$\%$ Rongga Thd Campuran (VIM) & 4.85 & 5.20 & 4.99 & 4.95 & $3-5$ \\
\hline Stabilitas, $(\mathrm{Kg})$ & 1700.91 & 1186.45 & 1652.49 & 1338.57 & $\min 1000$ \\
\hline Kelelehan,(mm) & 3.46 & 4.48 & 3.02 & 3.40 & $2-4$ \\
\hline Marshall Quotient (Kg/mm) & 523.09 & 269.38 & 540.54 & 431.01 & $\min 300$ \\
\hline Stabilitas Marshall Sisa (\%) & 90.80 & 91.90 & 96.90 & 92.60 & $\min 90 \%$ \\
\hline
\end{tabular}

Dari hasil tersebut, untuk rongga terhadap agregat dengan penambahan kadar Wetfix BE 0.2\% sampai dengan $0.4 \%$ memenuhi spesifikasi RSNI3 XXXX2014 yang mensyaratkan untuk rongga terhadap agregat minimal $15 \%$. Akan tetapi nilai rongga dalam agregat dengan menggunakan Wetfix BE lebih besar di banding tanpa menggunakan Wetfix BE, kenaikan tertinggi terjadi pada penambahan Wetfix BE $0.2 \%$ dengan persentase $2.39 \%$ dari kadar Wetfix BE $0.0 \%$.

Untuk kadar Wetfix BE $0.2 \%$ sampai dengan $0.4 \%$ memenuhi spesifikasi RSNI3 XXXX-2014 yang mensyaratkan untuk nilai rongga terisi aspal adalah $65 \%$. Akan tetapi rongga terisi aspal dengan menggunakan Wetfix $B E$ nilainya di bawah beton aspal tanpa menggunakan Wetfix BE, dengan persentase penurunan $2.03 \%, 0.81 \%$, dan $0.74 \%$ untuk kadar Wetfix BE $0.2 \%, 0.3 \%$, dan $0.4 \%$ terhadap kadar Wetfix BE $0.0 \%$.

Nilai rongga dalam campuran untuk kadar Wetfix $B E 0.3 \%$ dan $0.4 \%$ masuk ke dalam spesifikasi yang di syaratkan dalam RSNI3 XXXX-2014 yaitu 3\% $5 \%$. Nilai rongga dalam campuran ini cukup stabil, hanya penambahan Wetfix $B E 0.2 \%$ saja yang mengalami peningkatan $7.21 \%$ dari beton aspal tanpa
Wetfix $B E$ sehingga tidak memenuhi spesifikasi yang di syaratkan.

Dari hasil pengujian yang telah dilakukan untuk nilai stabilitas untuk kadar Wetfix BE $0.2 \%$ sampai dengan $0.4 \%$ memenuhi persyaratan RSNI3 XXXX2014 yaitu minimal $1000 \mathrm{~kg}$. Nilai stabilitas tertinggi dengan menggunakan Wetfix $B E$ yaitu pada kadar $0.3 \%$ sebesar $1652.9 \mathrm{~kg}$, dengan nilai stabilitas yang tinggi dapat menahan deformasi yang disebabkan oleh lalulintas berat. Akan tetapi stabilitas dengan menggunakan Wetfix $B E$ nilainya masih di bawah beton aspal tanpa menggunakan Wetfix BE.

Pelelehan merupakan parameter empirik untuk mengukur kelenturan campuran, yaitu kemampuan untuk mengikuti deformasi yang terjadi akibat lalu lintas, tanpa timbulnya retak dan perubahan volume. Dari Grafik 5.18. untuk nilai pelelehan yang memenuhi spesifikasi RSNI3 XXXX-2014 yaitu pada kadar Wetfix BE $0.30 \%$ dan $0.40 \%$. Dikatakan memenuhi spesifikasi karena nilai pelelehannya antara $2-4 \mathrm{~mm}$.

Dari hasil tersebut, nilai Marshall Quotient dengan bahan tambah Wetfix BE yang memenuhi spesifikasi minimal $300 \mathrm{~kg} / \mathrm{mm}$ yaitu pada kadar $0.20 \%$ dan $0.30 \%$. Nilai Marshall Quotient yang paling tinggi terjadi pada kadar Wetfix $B E 0.3 \%$, nilai Marshall Quotent yang tinggi ini menunjukkan campuran menjadi kaku dan fleksibilitas rendah. Sementara untuk penambahan Wetfix $B E$ dengan kadar $0.2 \%$ nilainya berada di bawah spesifikasi yang di syaratkan, nilai Marshall Quotion rendah ini menunjukkan campuran menjadi terlalu plastis dan mudah terjadi deformasi akibat beban lalu lintas.

Dari hasil pengujian untuk nilai stabilitas sisa dengan menggunakan Wetfix BE $0.2 \%, 0.3 \%$, dan $0.4 \%$ adalah $91.9 \%, 96.9 \%$, dan $92.6 \%$. Nilai tersebut memenuhi persyaratan RSNI3 XXXX-2014 yaitu minimal $90 \%$. Nilai stabilitas sisa yang paling tinggi di dapatkan pada kadar Wetfix $B E 0.3 \%$ dengan persentase peningkatan $6.72 \%$ dari kadar Wetfix $B E$ $0.0 \%$. Maka dari itu beton aspal dengan kadar Wetfix $B E 0.30 \%$ memiliki ketahanan yang tinggi terhadap kerusakan yang ditimbulkan oleh pengaruh air.

\section{IV.5 Hasil Pengujian Kekesatan}

Kekesatan permukaan adalah hal yang mutlak harus dimiliki oleh suatu lapis permukaan perkerasan lentur, terutama perkerasan lentur jalan tol, karena 
sudah ada Standar Pelayanan Minimum yang ditetapkan oleh Badan Pengatur Jalan Tol, dimana kekesatan permukaan dinyatakan dalam MuN $(M u$ Number). Nilai MuN ini didapat dari pengujian kekesatan di lapangan dengan menggunakan alat $\mathrm{Mu}-$ Meter (Chandra, 2011). Berikut hasil pengujian kekesatan.

Tabel 4.5. Hasil Pengujian Kekesatan

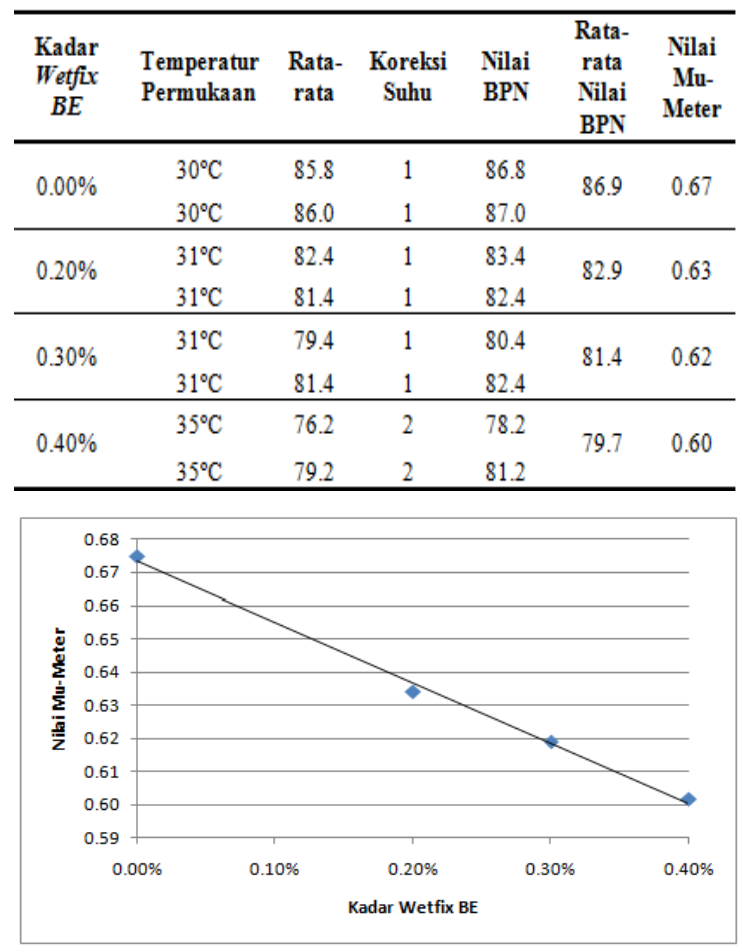

Gambar 4.1. Grafik Hubungan Kadar Wetfix BE dengan Kekesatan Permukaan

Secara umum nilai BPN yang di hasilkan oleh campuran tanpa menggunakan Wetfix $B E$ lebih tinggi dari pada campuran yang menggunakan Wetfix $B E$. Dan nilai BPN dari setiap campuran cenderung mengalami penurunan seiring bertambanya kadar Wetfix $B E$ dalam campuran. Nilai BPN tersebut berbanding lurus dengan nilai Mu-Meter, semakin besar nilai BPN maka semakin besar pula nilai $\mathrm{Mu}-$ Meter. Dari hasil yang di dapatkan untuk nilai $\mathrm{Mu}-$ Meter baik yang menggunakan dan tidak mengunakan Wetfix $B E$ nilainya memenuhi Peraturan Mentri
Pekerjaan Umum No. 16/PRT/M/2014 yaitu lebih dari $0.33 \mathrm{Mu}-$ Meter.

\section{IV.6 Hasil Pengujian Alur Roda (Wheel Tracking)}

Pengujian ini dilakukan untuk mengetahui nilai stabilitas dinamis dari benda uji yang menggunakan bahan tambah dan tanpa menggunakan Wetfix $B E$.

Tabel 4.6. Hasil Pengujian Alur Roda (Wheel Tracking)

\begin{tabular}{|c|c|c|c|c|c|c|}
\hline \multirow{2}{*}{ Waktu } & \multirow{2}{*}{ Passing } & \multicolumn{4}{|c|}{ Penambahan Wetfix BE } & \multirow{2}{*}{ Satuan } \\
\hline & & $0.00 \%$ & $0.20 \%$ & $0.30 \%$ & $0.40 \%$ & \\
\hline 0 & 0 & 0.00 & 0.00 & 0.00 & 0.00 & $\mathrm{~mm}$ \\
\hline 1 & 21 & 0.96 & 1.70 & 1.15 & 1.30 & $\mathrm{~mm}$ \\
\hline 5 & 105 & 1.80 & 2.62 & 1.93 & 2.27 & $\mathrm{~mm}$ \\
\hline 10 & 210 & 2.35 & 3.25 & 2.46 & 2.93 & $\mathrm{~mm}$ \\
\hline 15 & 315 & 2.71 & 3.72 & 2.85 & 3.45 & $\mathrm{~mm}$ \\
\hline 30 & 630 & 3.60 & 4.75 & 3.72 & 4.57 & $\mathrm{~mm}$ \\
\hline 45 & 945 & 4.23 & 5.55 & 4.42 & 5.38 & $\mathrm{~mm}$ \\
\hline 60 & 1260 & 4.75 & 6.14 & 5.02 & 6.02 & $\mathrm{~mm}$ \\
\hline \multicolumn{2}{|c|}{$\mathrm{DO}=\operatorname{Ren} \mathrm{Aw}$ al } & 2.67 & 3.07 & 2.27 & 2.27 & $\mathrm{~mm}$ \\
\hline \multicolumn{2}{|c|}{$\mathrm{RD}=$ Kecepatan Deformasi } & 0.0347 & 0.0393 & 0.0400 & 0.0423 & $\mathrm{~mm} / \mathrm{menit}$ \\
\hline \multicolumn{2}{|c|}{$\mathrm{DS}=$ Dinamis Stabilitas } & 1268.29 & 1067.80 & 1074.17 & 1014.84 & lintasan $/ m m$ \\
\hline
\end{tabular}

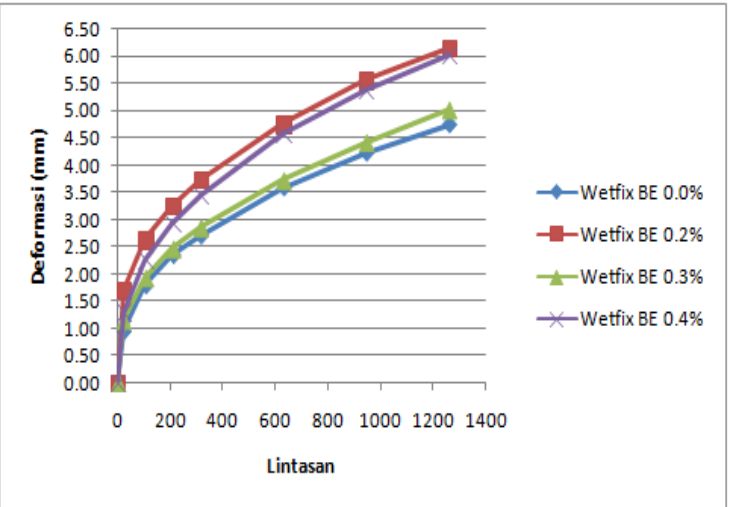

Gambar 4.2. Grafik Hubungan Deformasi Permanen dan Lintasan

Dari hasil pengujian alur roda pada suhu $60^{\circ} \mathrm{C}$ nilai laju deformasi dan nilai stabilitas dinamis untuk campuran dengan tanpa menggunakan bahan tambah Wetfix $B E$ lebih besar di bandingkan campuran menggunakan bahan tambah Wetfix BE. Hal ini dapat terjadi karena campuran tanpa menggunakan Wetfix $B E$ memiliki nilai stabilitas Marshall yang paling besar sehingga tahan terhadap deformasi yang terjadi. Untuk stabilitas dinamis beton aspal dengan menggunakan Wetfix BE tidak memenuhi persyaratan

Rikki Sofyan Rizal, Anni Susilowati, Heri Susanto 
RSNI3 XXXX-2014 yang mensyaratkan untuk beton aspal modifikasi minimal 2500 lintasan/mm, hal ini terjadi karena sesuai dengan fungsinya Wetfix $B E$ hanya meningkatkan daya lekat aspal terhadap agregat tidak untuk menaikkan stabilitas dinamis. Sementara untuk deformasi awal, nilai terbesar terjadi pada kadar Wetfix BE $0.2 \%$ yaitu $3.07 \mathrm{~mm}$.

\section{IV.7 Hasil Perhitungan Analisa Harga Satuan}

Analisis ini berisi tentang perbandingan harga bahan untuk lapis aus perkerasaan lentur dengan menggunakan bahan tambah Wetfix BE $0.3 \%$ dan tanpa menggunakan bahan tambah.

Tabel 4.7. Analisa Harga Satuan Tanpa Wetfix BE

\begin{tabular}{|c|c|c|c|c|c|}
\hline No & KOMPONEN & SATUAN & $\begin{array}{l}\text { PERKIRAAN } \\
\text { KUANTITAS }\end{array}$ & $\begin{array}{c}\text { HARGA } \\
\text { SATUAN } \\
\text { (Rp.) }\end{array}$ & $\begin{array}{c}\text { JULAH } \\
\text { HARGA } \\
\text { (Rp.) }\end{array}$ \\
\hline $\bar{A}$ & TENAGA KERJA & & & & \\
\hline 1 & Pekerja & Jam & 0.2389 & 10,000 & 2,389 \\
\hline 2 & Tukang & $\mathrm{Jam}$ & 0.1195 & 12,500 & 1,493 \\
\hline 3 & Mandor & Jam & 0.0597 & 18,500 & 1,105 \\
\hline \multicolumn{5}{|c|}{ JUMLAH BLAYA TENAGA KERJA } & 4,988 \\
\hline B & BAHAN & & & & \\
\hline 1 & Aspal Pen 60/70 & $\mathrm{kg}$ & 134.064 & 7,323 & 981,694 \\
\hline 2 & Screening & $\mathrm{m}^{2}$ & 0.851 & 285,400 & 242,984 \\
\hline 3 & Abu Batu & $\mathrm{m}^{2}$ & 0.713 & 231,000 & 164,634 \\
\hline 4 & Cement Portland & $\mathrm{kg}$ & 46.320 & 2,000 & 92,640 \\
\hline \multicolumn{5}{|c|}{ JUMAH BIAYA BAHAN } & $1,481,952$ \\
\hline $\mathrm{C}$ & PERALATAN & & & & \\
\hline 1 & Wheel Loader & Jam & 0.0763 & 400,000 & 30,520 \\
\hline 2 & Asphalt Mixing Plant & Jam & 0.0597 & $5,521,700$ & 329,645 \\
\hline 3 & Generator Set (Genset) & Jam & 0.0597 & 450,000 & 26,865 \\
\hline 4 & Dump Truck & Jam & 0.8587 & 175,000 & 150,266 \\
\hline 5 & Asphalt Finisher & Jam & 0.0747 & 420,400 & 31,404 \\
\hline 6 & Tandem Roller & $\mathrm{Jam}$ & 0.0511 & 275,300 & 14,068 \\
\hline 7 & Pneumatic Tire Roller & Jam & 0.0257 & 285,000 & 7,325 \\
\hline 8 & Alat Bantu & Ls & 1.0000 & 50,000 & 50,000 \\
\hline \multicolumn{5}{|c|}{$\begin{array}{c}\text { JUMLAH BIAYA PERALATAN } \\
\end{array}$} & 640,093 \\
\hline $\mathrm{D}$ & \multirow{2}{*}{\multicolumn{4}{|c|}{$\begin{array}{ll}\text { JUMLAH BIAYA TENAGA, BAHAN DAN PERALATAN }(A+B+C) & \\
\text { BIAYA UMUM DAN KEUNTUNGAN KONTRAKTOR } & 10 \%\end{array}$}} & $2,127,033$ \\
\hline E & & & & & 212,703 \\
\hline $\mathrm{F}$ & \multicolumn{4}{|c|}{ HARGA SATUAN PEKERJAAN PER M ${ }^{3}$} & $2,339,736$ \\
\hline $\mathrm{G}$ & \multicolumn{4}{|c|}{ HARGA SATUAN PEKERJAAN PER TON } & $1,044,525$ \\
\hline
\end{tabular}

Tabel 4.8. Analisa Harga Satuan dengan Wetfix $B E$ 0.3\%

\begin{tabular}{|c|c|c|c|c|c|}
\hline No & KOMPONEN & SATUAN & $\begin{array}{l}\text { PERKIRAAN } \\
\text { KUANTITAS }\end{array}$ & $\begin{array}{c}\text { HARGA } \\
\text { SATUAN } \\
\text { (Rp.) }\end{array}$ & $\begin{array}{c}\text { JMLAH } \\
\text { HARGA } \\
\text { (Rp.) }\end{array}$ \\
\hline$A$ & TENAGA KERJA & & & & \\
\hline 1 & Pekerja & Jam & 0.2389 & 10,000 & 2,389 \\
\hline 2 & Tukang & Jam & 0.1195 & 12,500 & 1,493 \\
\hline 3 & Mandor & Jam & 0.0597 & 18,500 & 1,105 \\
\hline \multicolumn{5}{|c|}{ JULAH BIAYA TENAGA KERJA } & 4,988 \\
\hline \multicolumn{6}{|c|}{ B BAHAN } \\
\hline 1 & Aspal Pen $60 / 70$ & $\mathrm{~kg}$ & 134.064 & 7,323 & 981,694 \\
\hline 2 & Screening & $\mathrm{m}^{2}$ & 0.851 & 285,400 & 242,984 \\
\hline 3 & Abu Batu & $\mathrm{m}^{2}$ & 0.713 & 231,000 & 164,634 \\
\hline 4 & Cement Portland & $\mathrm{kg}$ & 46.320 & 2,000 & 92,640 \\
\hline 5 & Wetfix BE & $\mathrm{Kg}$ & 0.402 & 75,000 & $30,164.40$ \\
\hline \multicolumn{5}{|c|}{ JULAH BLAYA BAHAN } & $1,512,116$ \\
\hline $\mathrm{C}$ & PERALATAN & & & & \\
\hline 1 & Wheel Loader & Jam & 0.0763 & 400,000 & 30,520 \\
\hline 2 & Asphalt Mixing Plant & $\mathrm{Jam}$ & 0.0597 & $5,521,700$ & 329,645 \\
\hline 3 & Generator Set (Genset) & $\mathrm{Jam}$ & 0.0597 & 450,000 & 26,865 \\
\hline 4 & Dump Truck & Jam & 0.8587 & 175,000 & 150,266 \\
\hline 5 & Asphalt Finisher & Jam & 0.0747 & 420,400 & 31,404 \\
\hline 6 & Tandem Roller & Jam & 0.0511 & 275,300 & 14,068 \\
\hline 7 & Pneumatic Tire Roller & Jam & 0.0257 & 285,000 & 7,325 \\
\hline 8 & Alat Bantu & Ls & 1.0000 & 50,000 & 50,000 \\
\hline \multicolumn{5}{|c|}{ JUMAH BIAYA PERALATAN } & 640,093 \\
\hline $\bar{D}$ & \multicolumn{4}{|c|}{ JUMAH BIAYA TENAGA, BAHAN DAN PERALATAN $(\mathrm{A}+\mathrm{B}+\mathrm{C})$} & $2,157,197$ \\
\hline E & \multicolumn{4}{|c|}{ BIAYA UMUM DAN KEUNTUNGAN K( $\quad 10 \%$} & 215,720 \\
\hline $\mathrm{F}$ & \multicolumn{4}{|c|}{ HARGA SATUAN PEKERJAAN PER $M^{s}$} & $2,372,917$ \\
\hline G & \multicolumn{4}{|c|}{ HARGA SATUAN PEKERJAAN PER TON } & $1,059,338$ \\
\hline
\end{tabular}

Dari hasil perhitungan harga satuan, untuk beton aspal normal lebih murah $\mathrm{Rp} 14,813$ per ton dari beton aspal dengan bahan tambah Wetfix BE $0.3 \%$. Akan tetapi dengan perbedaan harga Rp 14,813 ini untuk beton aspal dengan bahan tambah Wetfix $B E$ $0.3 \%$. Perbedaan biaya yang terjadi tidak terlalu signifikan karena beton aspal dengan bahan tambah Wetfix BE $0.3 \%$ hanya mengalami kenaikan $1.43 \%$ dari beton aspal normal.

\section{KESIMPULAN DAN SARAN}

\section{V.1 Kesimpulan}

Berdasarkan hasil pengujian yang telah dilakukan, didapat kesimpulan untuk menjawab masalah sebagai berikut :

1. Dari hasi percobaan laboratorium diperoleh nilai Kadar Aspal Optimum 6\%. Untuk sifat volumetrik beton aspal, campuran dengan menggunakan Wetfix BE mengalami penurunan kualitas dibanding campuran tanpa menggunakan Wetfix $B E$ yaitu dengan 
meningkatnya rongga dalam campuran dan menurunkan nilai rongga terisi aspal. Sementara untuk nilai stabilitas baik campuran tanpa dan dengan Wetfix $B E$ memenuhi spesifikasi yang ada, dengan nilai stabilitas terbesar pada campuran tanpa menggunakan Wetfix BE. Untuk nilai pelelehan dan Marshall Quotient hanya kadar Wetfix BE $0.20 \%$ yang tidak sesuai spesifikasi. Nilai stabilitas Marshall sisa yang didapat untuk kadar Wetfix BE $0.30 \%$ nilainya mengalami kenaikan paling besar yaitu $6.72 \%$ dari campuran tanpa menggunakan Wetfix $B E$. Dengan demikian penggunaan Wetfix $B E$ dalam campuran aspal tidak sepenuhnya meningkatkan nilai karakteristik Marshall.

2. Secara umum nilai BPN yang di hasilkan oleh campuran tanpa menggunakan Wetfix BE lebih tinggi dari pada campuran yang menggunakan Wetfix BE. Nilai BPN yang didapatkan berbanding lurus dengan nilai Mu-Meter, semakin besar nilai BPN yang di dapat maka semakin besar pula nilai $\mathrm{Mu}$-Meter. Nilai $\mathrm{Mu}-$ Meter untuk campuran tanpa dan dengan menggunakan Wetfix BE memenuhi persyaratan, yaitu lebih dari 0.33 Mu-Meter. Dengan memenuhi persyaratan tersebut maka permukaan jalan memiliki tahanan gesek antara ban dan permukaan jalan yang cukup baik, sehingga permukaan jalan tidak licin pada kondisi basah.

3. Dari hasil pengujian alur roda pada suhu $60^{\circ} \mathrm{C}$ nilai stabilitas dinamis untuk beton aspal tanpa menggunakan Wetfix $B E$ lebih besar di banding dengan menggunakan Wetfix $B E$. Dan untuk nilai laju deformasi untuk beton aspal tanpa menggunakan Wetfix $B E$ lebih kecil di banding beton aspal dengan menggunakan Wetfix $B E$. Dari hasil tersebut beton aspal yang lebih tahan terhadap deformasi yaitu pada campuran tanpa menggunakan Wetfix $B E$.

4. Dari hasil perhitungan harga satuan didapatkan untuk harga beton aspal tanpa Wetfix BE Rp 1,044,525 dan beton aspal dengan Wetfix $B E$ $0.3 \% \mathrm{Rp} 1,059,338$, Beton aspal tanpa Wetfix $B E$ lebih murah Rp 14,813 per ton dari beton aspal dengan bahan tambah Wetfix BE $0.3 \%$. Perbedaan biaya yang terjadi tidak terlalu berarti karena beton aspal dengan bahan tambah Wetfix $B E \quad 0.3 \%$ hanya mengalami kenaikan harga $1.43 \%$ dari beton aspal tanpa Wetfix $B E$. Perbedaan harga yang sangat kecil sebanding dengan hasil pengujian yang didapat, dengan menggunakan Wetfix BE $0.3 \%$ tidak menunjukkan kenaikan yang signifikan terhadap sifat mekanis beton aspal.

\section{V.2 Saran}

Berdasarkan hasil pengujian yang dilakukan disarankan :

1. Perlu dilakukan penelitian lebih lanjut untuk mengetahui lebih jauh kinerja dari Wetfix $B E$ dengan variasi kadar aspal dan persentase kadar Wetfix $B E$ yang berbeda.

2. Agar nilai stabilitas dinamis beton aspal dengan menggunakan Wetfix BE meningkat perlu di lakukan penelitian dengan penambahkan polimer pada aspal, polimer yang digunakan di sarankan yang sudah teruji sebelumnya.

\section{REFERENSI}

Akuba, Rohandi S, 2012, Pengaruh Pemakaian Aditif Wetfix-Be pada Campuran Asphalt Concrete Binder Course (AC-BC), Tugas Akhir. Universitas Negeri Gorontalo, Gorontalo.

Australian Roads, 2008, Guide To Pavement Technology Part 4J : Aggregate And Source Rock, Austroads, Sydney.

Basuki, Rachamad dan Machus, 2007, Penambahan Gilsonite Resin Pada Aspal Prima 55 untuk Meningkatkaan Kualitas Perkerasan Hot Mix, Jurnal Aplikasi Volume 3, Nomor 1, Agustus 2007, Surabaya.

Chandra, Denny, 2011, Perkerasan Jalan Tol, Metode Pemeliharaan Jalan Tol, Jakarta.

Departemen Pemukiman dan Prasarana Wilayah, 2002, Manual Pekerjaan Campuran Beraspal Panas, Jakarta

Eng, LS, Anti-Stripping Agents, New Technology in Hot Mix, Akzonobel Asphalt Application.

Gani, Dedy Rachman, 2013, Pengaruh Penggunaan Bahan Tambah Berbasis Hydrocarbon Terhadap Karakteristik Aspal Porus, Tugas Akhir. Universitas Hassanuddin, Makassar.

Hartini, Afrianti Sembiring dkk. 2011. Perbandingan Kinerja Anti Stripping Agent Wetfix Be dengan Derbo-401 UN 2735 Pada AC-WC 
yang Menggunakan Agregat dari Patumbuk. Universitas Sumatera Utara. Medan.

Hartini, Afrianti Sembiring dan Muis, Zulkarnain A. 2012. Pengaruh Variasi Antistripping Agent Terhadap Karakteristik Beton Aspal Lapis Aus (AC-WC). Universitas Sumatera Utara. Medan.

Husni, Amul dan Shiria, Tantalia, 2002, Evaluasi Kinerja Marshall dan Deformasi Campuran Beraspal dengan Gradasi Superpave, Tugas Akhir, Istitut Teknologi Bandung, Bandung.

JRA-1980, Pengujian Stabilitas Dinamis Dengan Menggunakan Wheel Tracking Machine, Jepang, 1980.

Kusdiyono, 2009, Komparasi Pengaruh Gradasi Agregat Batas Bawah dengan Bergradasi Batas Atas Terhadap Karakteristik Marshall pada Beton Aspal Campuran Panas, Wahana TEKNIK SIPIL Vol. 14 No. 3 Agustus 2009.

Latifa, Eva Azhra, dkk. 2013. Stabilitas Dinamis Beton Aspal Campuran Panas Dibawah Variasi Temperatur. Politeknologi Vol.12 No.4 Januari 2013

Masykur, 2011, Analisa Uji Simulasi Pembebanan WTM Pada Lapis Tipis Aspal Beton (LATASTON), Tapak, Jakarta.

Mulyono, dkk. 2010, Dampak Gradasi Agregat Dengan Dua Variasi Aspal Terhadap Sifat Campuran Beton Aspal, Prosiding Seminar Nasional Teknik Sipil 2010. Volume 04 Tahun 2010.

Nono, 2005, Kinerja Campuran Beton Aspal Dengan Pengikat Aspal yang Dimodifikasi Asbuton, Puslitbang Prasarana Transportasi, Bandung.

Panjaitan, Chandra Benny dan Muis, Zulkarnain A, 2014, Studi Pengaruh Penggunaan Variasi Anti Stripping Agent Wetfix Be Dan Derbo401 Terhadap Karakteristik Campuran Beton Aspal Lapis Pondasi Atas (Ac-Base), Jurnal Teknik Sipil Usu Volume 3 No.1 2014

Pedoman Pt-T-01-2002-B, 2002, Pedoman Perencanaan Tebal Perkerasan Lentur, Depertemen Pemukinan dan Prasarana Wilayah.

Pedoman Pd.T-04-2005-B, 2005, Spesifikasi Umum Bidang Jalan dan Jembatan Pusat Litbang.
RSNI3 XXXX-2014, 2014, Spesifikasi Campuran Beraspal Panas Bergradasi Menerus (Laston), Badan Standarisasi Nasional.

Sukirman, Silvia. 2003. Beton Aspal Campuran Panas. Edisi 1. Jakarta : Granit.

Silaen, Rosserdo M. H. J., 2013, Stabilitas Dinamis Beton Aspal Campuran Panas dengan Agregat Bergradasi Superpave, Tugas Akhir, Politeknik Negeri Jakarta, Depok.

SNI 03-1968-1990, Metode Pengujian Analisis Saringan Agregat Halus dan Kasar, Badan Standar Nasional, 1990.

SNI 03-1971-1990, Metode Pengujian Kadar Air Agregat Halus dan Kasar, Badan Standar Nasional, 1990.

SNI 03-4142-1996, Metode Pengujian Agregat Lolos Saringan No. 200, Badan Standar Nasional, 1996.

SNI 03-4804-1998, Metode Pengujian Berat Isi Agregat Halus dan Kasar, Badan Standar Nasional, 1998.

SNI 06-2489-1991, Metode Pengujian Marshall, Badan Standar Nasional, 1991.

SNI 1969-2008, Cara Uji Berat Jenis dan Penyerapan Air Agregat Kasar, Badan Standar Nasional, 2008.

SNI 1970-2008, Cara Uji Berat Jenis dan Penyerapan Air Agregat Halus, Badan Standar Nasional, 2008.

SNI 4427 : 2008, Cara Uji Kekesatan, Badan Standar Nasional, 2008.

SNI 2432:2011, Cara Uji Daktilitas Aspal, Badan Standar Nasional, 2011.

SNI 2441:2011, Cara Uji Berat Jenis Aspal Padat, Badan Standar Nasional, 2011

SNI 2456-2011, Cara Uji Penetrasi Aspal, Badan Standar Nasional, 2011.

The Asphalt Institute, 1996, Superpave Mix Design, Asphalt Institute, Washington 